\title{
Prevalence and predictors of dental caries and trauma among institutionalised and non-institutionalised street children in Ibadan.
}

${ }^{1}$ Ayebameru O.E, ${ }^{2}$ Popoola B., ${ }^{2}$ Denloye O.

${ }^{1}$ University of Medical Sciences Teaching Hospital, Ondo, Ondo State, Nigeria.

${ }^{2}$ University College Hospital, Ibadan, Nigeria.

\begin{abstract}
Objective: Urbanization is increasing the number of street children in most regions of the world especially in many African cities which may be due to poverty and unemployment status of many parents. This study was aimed at determining the predictors and prevalence of dental caries and trauma among institutionalized (those in juvenile correctional home) and non-institutionalized street children in Ibadan.

Methods: This cross-sectional study was carried out among institutionalized (juvenile correctional home) and non-institutionalized street children. Cluster sampling technique was used in the selection of children for this study. Children were selected from the juvenile correctional home and four major motor parks in Ibadan metropolis.

Results: One hundred and thirty eight children participated in this study. Male constituted $65.9 \%$ while female was $34.1 \%$. Thirty five $(25.4 \%)$ are from the juvenile correctional home (institutionalized street children) while $103(74.6 \%)$ are from the streets. The prevalence of dental caries among the children generally was $29.0 \%$, while that of dental trauma was $18.8 \%$.

Conclusion: The significant predictors of dental caries were gender, tooth hypoplasia and the presence of visible plaque on the anterior teeth while those of dental trauma were lip competence, substance use, age and gender.

Keywords: Street children, Juvenile home, Caries, Trauma.
\end{abstract}

INTRODUCTION: Street children include those boys and girls for whom the street in its widest sense has become their habitual residence or source of livelihood. They are inadequately protected, supervised, or directed by responsible adults ${ }^{1}$. Broadly, these children can be categorized into: children of the street, children on the street, children who are part of a street family, and those in institutionalized care such as the Juvenile correctional home ${ }^{1}$. Urbanization is increasing the number of street children in most regions of the world especially in many African cities which may be due to poverty a $\mathrm{d}$ u n e m ployment status of many parents. According to Ebigbo $^{3}$, an average population of working children per hour per street reported were

Correspondence :Ayebameru O.E

University of Medical Sciences, Ondo, Ondo State, Nigeria

Email Address: brodashow@yahoo.com

Tel: +2348066271140

Received: 05/12/2018

Accepted:03/09/2019

https://dx.doi.org/10.4314/ajoh.v9i1.4
44.4, 195.9 and 193.1 in Enugu, Kaduna and Ibadan respectively. The inmates of Ibadan remand home have fluctuated between 59 and 64 between 1976 and $2010^{4.5}$. These children are said to have been under represented in health research for long. They also have little or no access to the conventional healthcare system, yet they are plagued with myriad of both general and oral health challenges ${ }^{6-8}$. Over half of abandoned street boys and girls reported health problems including dental caries ${ }^{7}$. Their use of dental services is less than the general population ${ }^{8}$. Some of their daily habits make them to be especially prone to oral health problems. These habits include, but not limited to regular substance abuse and poor oral hygiene practices. Dental caries prevalence among street children in Mexico was found to be $94.6 \%$, while another study in a Midwest urban city was 50.3\% showing a higher prevalence compared to the national average $^{10}$. Srinivas et $\mathrm{al}^{11}$, in India found that $50.2 \%$ of institutionalized children had dental caries while a similar study in Brazil revealed a prevalence of $93.1 \%{ }^{12}$. There is paucity of data concerning the prevalence of 
dental caries among street children in Nigeria. Although dental trauma was found to be prevalent among $90 \%$ of incarcerated youth screened in Toronto-area youth centre ${ }^{13}$, there still seems to be a dearth of information on recent reviews pertaining to its prevalence among street children both in this environment and globally. Meanwhile, varying prevalence of dental trauma have been reported from studies carried out among other children in Nigeria ${ }^{14-}$ ${ }^{19}$. Predictors of dental caries generally include diets, oral hygiene and other host factors while those of dental trauma include Angles' Class II division 1 malocclusion, gender and certain sociodemographic factors ${ }^{20,2,1}$. This study was aimed at determining the prevalence and predictors of dental caries and trauma among non-institutionalized and institutionalized street children in Ibadan due to limited information about these dental challenges among these groups of children in addition to their poor access to healthcare.

\section{METHODS}

This was a cross-sectional study carried out among institutionalized (juvenile correctional home) and non-institutionalized street children. Cluster sampling technique was used in the selection of children for this study. Ibadan metropolis has one juvenile correctional home, and all the 7 - 15 years old children in the institution were recruited. For the selection of non-institutionalized streets children, two Local Government Areas (LGAs) out of the five in Ibadan metropolis were randomly selected by balloting. Out of these two LGAs, two major motor parks, where street children could be located were randomly selected by balloting from each of the local government areas. All the street children between the ages of 7 and 15 years in these four selected major motor parks were recruited into the study. The children were categorized into age groups of 7-9, $10-$ 12 and $13-15$. Those in age groups 7-9 and 10-12 were in mixed dentition years where there will be likelihood of poor oral hygiene due to the discomfort experienced while brushing mobile deciduous teeth. At age 13-15 years, they become more active in contact sports and experimenting with substance use. They also have access to more cariogenic diets as a result of earnings from menial jobs they were involved in on the street. The Sample size was calculated using the formula ${ }^{22} n=Z^{2} p q / d^{2}$. Where $n=$ the desired sample size, $z=$ the standard normal deviate set at 1.96 (corresponding to $95 \%$ confidence level), $q=1.0-p, d=$ degree of accuracy desired, set at 0.05 (5\%). With an estimated prevalence of $10 \%$, the calculated sample size was 138. Interviewer-administered questionnaire was utilized in obtaining the demographic information (age and gender)of each child, frequency of tooth cleaning, tooth cleaning materials (tooth brush, chewing stick and others like the use of finger and cotton wool), frequency of daily snacking in between meals and the use of psycho-active substances which may predispose them to violence that can make them sustain physical injury and dental trauma. Intra-oral examination was done under natural light and caries detection was done using the Classification of carious lesions by G.V. Black ${ }^{23}$ with its modification, and the World Health Organization $(\mathrm{WHO})^{24}$ code description for scoring caries experience. Sterile mouth mirror and CPI probe were used for this purpose. For the assessment of the predictors of dental caries, salivary function and duct patency was done by drying the Stenson's duct on the buccal mucosal using sterile gauze and gently massaging or squeezing the duct until saliva was expressed with the time taken to express saliva for each child was noted ${ }^{25}$ and oral hygiene using Simplified Oral Hygiene index of Greene and Vermillion $^{26}$. Furthermore, presence of visible plaque on anterior teeth, presence of gingivitis using the gingival index of Löe and Silness ${ }^{27}$, presence of white spot lesions on drying each tooth with manual pump, presence of teeth with enamel hypoplasia and retentive pits and fissures were assessed. Also determined were the predictors of dental trauma which include some predisposing anatomical factors that may increase the susceptibility to dental injuries, among which are Angle's Class II division 1 malocclusion, increased over-jet (greater than $4 \mathrm{~mm}$ ), anterior open bite, short or hypotonic upper lip and oral breathing individuals. Other factors assessed include the presence of an existing traumatic dental injuries, using Ellis classification 28. Classes VI - IX were not assessed because no radiographs were taken. Data processing was carried out with the aid of SPSS version 21(SPSS Inc., Chicago Illinois, USA). Summary statistics (frequency, percentage) were performed to determine the prevalence and pattern of presentation. Chi square was used for categorical variables and t-test was used for continuous variables in determining the relationship/association between variables. An observation was considered significant 
when the $\mathrm{p}$ value is $\leq 0.05$. Ethical approval was obtained from University of Ibadan/University College Hospital Ethical Review Committee before commencement of the study. Approval for the study was sought from the Oyo State Ministry of Women Affairs, Community Development and Social Welfare. Parental consent was waived in view of the difficulties that were encountered in tracing the parents of the noninstitutionalized street children while care-givers in juvenile correctional homes (Institutionalized) were 'locus parentis' and consent obtained from them. Individual assent was obtained from the children.

\section{RESULTS}

One hundred and thirty eight street children participated in this study. There were 91 (65.9\%) males and $47(34.1 \%)$ females. Thirty five $(25.4 \%)$ were from the juvenile correctional home (institutionalized street children) while 103 (74.6\%) were noninstitutionalized. (Table 1) The prevalence of dental caries among the children generally was $29.0 \%$.

(Tables 2) Prevalence of dental caries among the institutionalized children was $20.0 \%$. More females $(23.1 \%)$ than the males $(18.2 \%)$ were affected. Fifty per cent of those aged 7-9, $11.8 \%$ of those within $10-12$ and $21.4 \%$ of $13-15$ had dental caries. (Table 3 ) On the other hand, the prevalence of dental caries among the noninstitutionalized group was $32.0 \%$. (Table 4 ) The prevalence of dental trauma among the studied children generally was $18.8 \%$ (Table 5). That of the institutionalized children was $25.7 \%$ (Table 6), while it was $16.5 \%$ among non-institutionalized street children (Table 7). Statistically significant predictors of dental caries identified among the combined groups of children were gender, presence of visible plaque on anterior teeth, tooth cleaning materials, hypoplasia and gingivitis $(p<0.05)$ (Table 2). None of the predictors of dental caries among the institutionalized and non-institutionalized street children was found to be statistically significant among the children (Table 4). However, it was observed among the non-institutionalized street children that females (32.4\%) were more affected than the males (31.9\%). Also, $47.1 \%$ of those in ages $7-9$ were affected compared to $27.7 \%$ of $10-12$ and $30.8 \%$ of $13-$ 15 (Table 5). Among the two groups of children, more males $(23.1 \%)$ than females $(10.6 \%)$ suffered dental trauma (Table 5). Lip competence was the only statistically significant p r e d i c t o r of de n ta 1 tr aum a a mong the institutionalized children $(p<$
0.05). Also, among institutionalized children, only $25 \%$ of those without Anterior Open Bite (AOB) had dental trauma whereas, as much as $33.3 \%$ of those with $\mathrm{AOB}$ were affected by dental trauma (Table 6). Among the noninstitutionalized street children, age, gender and substance use were the statistically significant predictors of dental trauma $(p<0.05)$. Also, among these children, $20 \%$ of those with AOB had dental trauma while only $16.3 \%$ of those without $\mathrm{AOB}$ were involved (Table 7).

\section{DISCUSSION}

The prevalence of dental caries among the children in this study was found to be higher than the average prevalence in the previous studies among school children in this environment ${ }^{15,29}$. This may be attributable to the poorer oral hygiene status observed among street children compared to school children ${ }^{8,30}$. On the other hand, the prevalence among the institutionalized street children is lower compared to the findings of some previous studies ${ }^{11,12}$. Similarly, the prevalence found among the noninstitutionalized street children is lower compared to the study of Contreras-Bulnes et $\mathrm{al}^{9}$ in Mexico and Chiu et al $^{10}$ among African-American homeless children. The reasons for the disparities observed between these previous studies and the present study may be related to cheap and abundant availability of cariogenic snacks in developed countries. Also, the possibility of differences in diets among the populations involved, such that, in between meals seem impossible among Nigerian institutionalized and non-institutionalized street children due to economic reasons, a situation that may be different in the western societies. Comparatively, the prevalence of dental caries among non-institutionalized children is higher than that of institutionalized children in this study. This might be related to the fact that majority of the noninstitutionalized street children live an independent life where there is no parental guidance or any responsible adult influence thereby squandering the little money they make on cariogenic diets. These are similar to some of the reasons observed by Kahabuka and Mbawalla ${ }^{30}$. Furthermore, the prevalence of dental trauma among children in this study was slightly higher compared to the observations in previous studies among school children by Otuyemi ${ }^{14}$, Adekoya-Sofowora et $\mathrm{al}^{15}$, and Ajayi et $\mathrm{al}^{31}$. This may be related the lifestyle of substance use and abuse, and the predominance of 
violence among street children ${ }^{8}$. Also, those of the institutionalized and non-institutionalized children were also higher than the report of a previous study ${ }^{11}$. This previous study was carried out among institutionalized street children who must have had adequate number of staff carefully watching over the children to prevent activities that may lead to dental trauma among them. Comparison of dental trauma prevalence between the two groups of children in this study found a higher prevalence among the institutionalized group. It is obvious that both groups of children were prone to dental trauma. It is understandable why the prevalence of dental trauma in juvenile correctional home (institutionalized children) was higher when taken separately considering the fact that most of the children were taken from the streets where they had a history of unbridled freedom, independence and violence. On their arrival at the juvenile correctional home, they would find themselves in the midst of other children from the streets, hence, fights for territoriality could ensue to increase their risks of dental trauma. Among all the predictors considered for dental caries in the present study, gender, tooth cleaning materials, tooth hypoplasia, the presence of visible plaque on the anterior teeth and gingivitis were statistically significant.

The findings in the present study was similar to those of previous studies where it was reported that dental caries experience was more common among children who had enamel hypoplasia and developmental defects of enamel in their posterior teeth than among those with none of these defects ${ }^{32,33}$. This was also in agreement with the study of Pascoe and Seow ${ }^{34}$ and Hong et $\mathrm{al}^{35}$ who reported that a strong association exists between enamel hypoplasia and dental caries. This may be attributed to the fact that such defects provide a favourable local environment for adhesion and colonization of cariogenic bacteria which may remain at the base of the defect in contact with exposed dentin thereby leading to dental caries formation ${ }^{36}$. Also, defective enamel has been found to have higher acid solubility than normal enamel, making it more susceptible to caries attack ${ }^{36,37}$. Furthermore, the results of this study show that there is slight gender difference on the development of dental caries with the female gender being slightly more prone than male. This is in agreement with Ur- Rehman et $\mathrm{al}^{38}$ who reported a higher mean DMFT for girls compared to boys. This may be attributable to the fact that female tend to consume refined carbohydrates more frequently than males ${ }^{39}$. However, Dawani et al, ${ }^{40}$ had reported that the mean $\mathrm{dmft}$ for males was higher compared to females, although some studies reported that there is no difference in the prevalence of dental caries between male and female ${ }^{41-42}$. Presence of visible plaque on the labial aspect of the lower anterior teeth, which is indicative of poor oral hygiene, was significantly linked with dental caries in this study. Generally, street children have been found to have a tendency for a poorer oral hygiene compared to those who are not on the street which will predispose them to development of carious lesions ${ }^{30}$. This is in line with a few previous reports ${ }^{43,4}$. However, some studies concluded that there is a only weak evidence showing that brushing of teeth prevents dental caries $^{21,45}$. Inadequate oral hygiene predisposes to plaque accumulation leading to gingivitis which is also found to be a predictor of dental caries in this present study. Tooth brushing had been recommended as a tool against dental caries and gingivitis ${ }^{21,46}$. Tooth cleaning material was also found to be significantly associated with dental caries in this present study. This is in line with the previous studies where it has been observed that chewing stick is as effective as a toothbrush for reducing plaque on tooth surfaces ${ }^{47,48}$. Dental caries among those between ages 7 and 9 years was found to be higher compared to those who are 10 -12 and $13-15$ years. These 7 to 9 year old children are in the mixed dentition period where the mobile deciduous teeth are not adequately cleaned because of pain and the fear of traumatic exfoliation. This is in agreement with Demirci et $\mathrm{al}^{49}$ and $\mathrm{Al}-\mathrm{Sultani}{ }^{50}$ who found that the incidence of dental caries decreases with age. However this finding was not in agreement with that of Sogi et $\mathrm{al}^{51}$ and Fonseca et $\mathrm{al}^{52}$ where dental caries experience on permanent teeth were found to be worsened with increase in age. Ur-Rehman et $\mathrm{al}^{38}$ also found that dental caries is most prevalent within the ages of 11 and 14 years. However, Sgan-Cohen et $\mathrm{al}^{53}$ reported no difference among different age groups as regards dental caries prevalence. Considering the predictors of dental trauma, lip competence (among the institutionalized street children), substance use, age and gender (among noninstitutionalized street children) were the statistically significant predictors. Incompetent lip seal may be due to the absence of the cushioning effects of the lips during a fall or any accident thereby exposing the anterior teeth to dental injuries. This 
Table 1: Distribution of the participating children

\begin{tabular}{|c|c|c|}
\hline Variable & $\mathbf{N}$ & $\%$ \\
\hline \multicolumn{3}{|l|}{ Group } \\
\hline Non -institutionalized & 103 & 74.6 \\
\hline Institutionalized & 35 & 25.4 \\
\hline Total & 138 & 100.0 \\
\hline \multicolumn{3}{|l|}{ Sex } \\
\hline Male & 91 & 65.9 \\
\hline Female & 47 & 34.1 \\
\hline Total & 138 & 100.0 \\
\hline \multicolumn{3}{|l|}{ Age } \\
\hline $7-9$ & 21 & 15.2 \\
\hline $10-12$ & 64 & 46.4 \\
\hline $13-15$ & 53 & 38.4 \\
\hline Total & 138 & 100.0 \\
\hline \multicolumn{3}{|l|}{ School } \\
\hline Yes & 112 & 81.2 \\
\hline No & 26 & 18.8 \\
\hline Total & 138 & 100.0 \\
\hline \multicolumn{3}{|l|}{ Caries } \\
\hline Yes & 40 & 29.0 \\
\hline No & 98 & 71.0 \\
\hline Total & 138 & 100.0 \\
\hline \multicolumn{3}{|l|}{ Trauma } \\
\hline Yes & 26 & 18.8 \\
\hline No & 112 & 81.2 \\
\hline Tot al & 138 & 100.0 \\
\hline
\end{tabular}

Table 2: Association between the predictors of dental caries and prevalence among the children

\begin{tabular}{|c|c|c|c|c|c|}
\hline \multirow[t]{2}{*}{ Predictors } & \multicolumn{2}{|c|}{ Dental Caries } & \multirow[t]{2}{*}{ Total } & \multirow[t]{2}{*}{2} & \multirow[t]{2}{*}{ p-value } \\
\hline & Yes & No & & & \\
\hline \multicolumn{6}{|l|}{ Sex } \\
\hline Male & $26(28.6)$ & $5(71.4)$ & $91(100.0)$ & \multirow{3}{*}{0.88} & \multirow{3}{*}{0.02} \\
\hline Female & $14(29.8)$ & $3(70.2)$ & $47(100.0)$ & & \\
\hline Total & $40(29.0)$ & $8(71.0)$ & 138(100.0) & & \\
\hline \multicolumn{6}{|l|}{ Age } \\
\hline $7-9$ & $10(47.6)$ & $11(52.4)$ & $21(100.0)$ & \multirow{4}{*}{0.11} & \multirow{4}{*}{4.51} \\
\hline $10-12$ & 15(23.4) & $49(76.6)$ & $64(100.0)$ & & \\
\hline $13-15$ & $15(23.5)$ & $38(71.7)$ & $53(100.0)$ & & \\
\hline Total & $40(29.0)$ & 98(71.0) & 138(100.0) & & \\
\hline \multicolumn{6}{|l|}{ Frequency of tooth cleaning } \\
\hline Once daily & $31(31.6)$ & $67(68.4)$ & $98(100.0)$ & \multirow{4}{*}{3.76} & \multirow{4}{*}{$0.15^{*}$} \\
\hline Twice daily & $7(31.8)$ & $15(68.2)$ & $22(100.0)$ & & \\
\hline Less than once daily & $2(11.8)$ & $16(88.9)$ & $18(100.0)$ & & \\
\hline Total & $40(29.8)$ & 98(71.0) & 138(100.0) & & \\
\hline \multicolumn{6}{|l|}{ Tooth cleaning materials } \\
\hline Tooth brush and paste & $36(27.3)$ & $96(72.7)$ & 132(100.0) & \multirow{4}{*}{6.46} & \multirow{4}{*}{$0.04^{*}$} \\
\hline Tooth brush and chewing stick & $4(80.0)$ & $1(20.0)$ & $4(100.0)$ & & \\
\hline Others & $0(0.0)$ & $1(100.0)$ & $1(100.0)$ & & \\
\hline Total & $40(29.0)$ & $98(71.0)$ & 138(100.0) & & \\
\hline
\end{tabular}




\begin{tabular}{|c|c|c|c|c|c|}
\hline \multicolumn{6}{|l|}{ Salivary flow } \\
\hline Before 1 minute & $40(29.4)$ & $96(70.6)$ & 136(100.0) & \multirow{3}{*}{0.83} & \multirow[b]{2}{*}{$1.00^{*}$} \\
\hline After 1 minute & $(0.0)$ & $2(100.0)$ & $2(100.0)$ & & \\
\hline Total & $40(29.0)$ & $98(71.0)$ & 138(100.0) & & \\
\hline \multicolumn{6}{|c|}{ Presence of visible plaque on anterior teeth } \\
\hline Yes & $31(29.0)$ & $76(71.0)$ & 107(100.0) & \multirow{3}{*}{0.99} & \multirow{3}{*}{0.00} \\
\hline No & $9(29.0)$ & $22(71.0)$ & $31(100.0)$ & & \\
\hline Total & $40(29.0)$ & 98(71.0) & 138(100.0) & & \\
\hline \multicolumn{6}{|c|}{ Presence of deeppits and fissures } \\
\hline Yes & $3(50.0)$ & $3(50.0)$ & $6(100.0)$ & \multirow[t]{3}{*}{0.25} & \multirow[t]{3}{*}{$1.35^{*}$} \\
\hline No & $37(28.0)$ & $95(72.0)$ & 132(100.0) & & \\
\hline Total & $40(29.00)$ & 98(71.0) & 138(100.0) & & \\
\hline \multicolumn{6}{|c|}{ Presence of enamel hypoplasia } \\
\hline Yes & $1(33.3)$ & $2(66.7)$ & $3(100.0)$ & \multirow{3}{*}{0.87} & \multirow{3}{*}{$0.03^{*}$} \\
\hline No & $39(28.9)$ & $96(71.1)$ & 135(100.0) & & \\
\hline Total & $40(29.0)$ & $98(71.0)$ & 138(100.0) & & \\
\hline \multicolumn{6}{|c|}{ Frequency of sugar snack consumption } \\
\hline Less than three times daily & $29(26.1)$ & $82(73.9)$ & 111(100.0) & \multirow{3}{*}{0.44} & \multirow{3}{*}{2.69} \\
\hline Three or more times daily & 11(40.7) & $16(59.3)$ & 27(100.0) & & \\
\hline \multirow[t]{2}{*}{ Total } & $40(29.0)$ & $98(71.0)$ & 138(100.0) & & \\
\hline & & & & $t$ test & Sig value \\
\hline Oral hygiene & $2.1 \pm 0.92$ & $2.21 \pm 1.14$ & & 0.25 & 0.51 \\
\hline Gingivitis & $1.10 \pm 0.30$ & $1.21 \pm 0.50$ & & 1.34 & 0.01 \\
\hline
\end{tabular}


Table 3:Association between the predictors of dental caries and prevalence among institutionalized street children.

\begin{tabular}{|c|c|c|c|c|c|}
\hline \multirow[t]{4}{*}{ Risk Factors } & \multicolumn{2}{|c|}{ Dental Caries } & \multirow{4}{*}{$\begin{array}{l}\text { Total } \\
\text { N (\%) } \\
\text { 35(100.0) }\end{array}$} & \multirow[t]{4}{*}{$x^{2}$} & \multirow[t]{4}{*}{$p$-value } \\
\hline & Yes & No & & & \\
\hline & $n(\%)$ & $N(\%)$ & & & \\
\hline & $7(\mathbf{1 0 0 . 0 )}$ & $28(100.0)$ & & & \\
\hline \multicolumn{6}{|l|}{ Age (years) } \\
\hline $7-9$ & $2(50.0)$ & $2(50.0)$ & $4(100.0)$ & & \\
\hline $10-12$ & $2(11.8)$ & $15(88.2)$ & $17(100.0)$ & 2.9 & $0.22^{*}$ \\
\hline $12-15$ & $3(21.4)$ & 11(78.6) & $14(100.0)$ & & \\
\hline Total & $7(20.0)$ & $28(80.0)$ & $35(100.0)$ & & \\
\hline \multicolumn{6}{|l|}{ Sex } \\
\hline Male & $4(18.2)$ & $18(81.8)$ & $22(100.0)$ & & \\
\hline Female & $3(23.1)$ & 10(76.9) & $13(100.0)$ & 0.12 & $0.73^{*}$ \\
\hline Total & $7(20.0)$ & $28(80.0)$ & $35(100.0)$ & & \\
\hline \multicolumn{6}{|l|}{ Frequency of tooth cleaning } \\
\hline Once daily & $4(23.5)$ & $13(76.5)$ & $17(100.0)$ & & \\
\hline Twice daily & $1(33.3)$ & $2(66.7)$ & $3(100.0)$ & 0.88 & 0.64 \\
\hline Less than once daily & $2(13.3)$ & $13(86.7)$ & $15(100.0)$ & & \\
\hline Total & $7(20.0)$ & $28(80.0)$ & $35(100.0)$ & & \\
\hline \multicolumn{6}{|l|}{ Tooth cleaning materials } \\
\hline Tooth brush and paste & $6(17.6)$ & $28(82.4)$ & $34(100.0)$ & & \\
\hline Toothbrush \& chewing stick & $1(100.0)$ & $0(0.0)$ & $1(100.0)$ & 4.11 & 0.20 \\
\hline Others & $0(0.0)$ & $0(0.0)$ & $0(0.0)$ & & \\
\hline Total & $7(20.0)$ & $28(80.0)$ & 35(100.) & & \\
\hline Before 1 minute & $7(20.0)$ & $28(80.0)$ & $35(100.0)$ & & \\
\hline After 1 minute & $0(0.0)$ & $0(0.0)$ & $0(0.0)$ & - & - \\
\hline Total & $7(20.0)$ & $28(80.0)$ & $35(100.0)$ & & \\
\hline \multicolumn{6}{|l|}{ Presence of visible plaque } \\
\hline Yes & $5(17.2)$ & $24(82.8)$ & $29(100.0)$ & & \\
\hline No & $2(33.3)$ & $4(66.7)$ & $6(100.0$ & 0.81 & $0.37^{*}$ \\
\hline Total & $7(20.0)$ & $28(80.0)$ & $35(100.0)$ & & \\
\hline \multicolumn{6}{|l|}{ Presence of white spot lesions } \\
\hline Yes & $7(20.0)$ & $28(80.0)$ & $35(100.0)$ & & \\
\hline No & $0(0.0)$ & $0(0.0)$ & $0(0.0)$ & - & - \\
\hline Total & $7(20.0)$ & $28(80.0)$ & $35(100.0)$ & & \\
\hline \multicolumn{6}{|c|}{ Presence of deep pits and fissures } \\
\hline Yes & $7(20.0)$ & $28(80.0)$ & $35(100.0)$ & & \\
\hline No & $0(0.0)$ & $0(0.0)$ & $0(0.0)$ & - & - \\
\hline Total & $7(20.0)$ & $28(80.0)$ & $35(100.0)$ & & \\
\hline \multicolumn{6}{|l|}{ Intra-Oral appliances } \\
\hline Yes & $0(0.0)$ & $0(0.0)$ & $0(0.0)$ & & \\
\hline None & $7(20.0)$ & $28(80.0)$ & $35(100.0)$ & - & - \\
\hline Total & $7(20.0)$ & $28(80.0)$ & $35(100.0)$ & & \\
\hline \multicolumn{6}{|l|}{ Presence of enamel hypoplasia } \\
\hline Yes & $7(20.6)$ & $27(79.4)$ & $34(100.0)$ & & \\
\hline No & $0(0.0)$ & $1(100.0)$ & $1(100.0)$ & 0.26 & $0.61^{*}$ \\
\hline Total & $7(20.0)$ & $28(80.0)$ & $35(100.0)$ & & \\
\hline \multicolumn{6}{|l|}{ Frequency of sugar snack } \\
\hline None & $0(0.0)$ & $1(100.0)$ & $1(100.0)$ & & \\
\hline Less than 3 times/day & $7(21.2)$ & $26(78.8)$ & $33(100.0)$ & 0.27 & $0.61^{*}$ \\
\hline 3 or more timely/day & $0(\mathbf{0})$ & $1(100.0)$ & $1(100.0)$ & & \\
\hline 3 or more times/day & $7(20.0)$ & $28(80.0)$ & $35(100.0)$ & & \\
\hline
\end{tabular}


Table 4: Association between the predictors of dental caries and prevalence among non-institutional street children

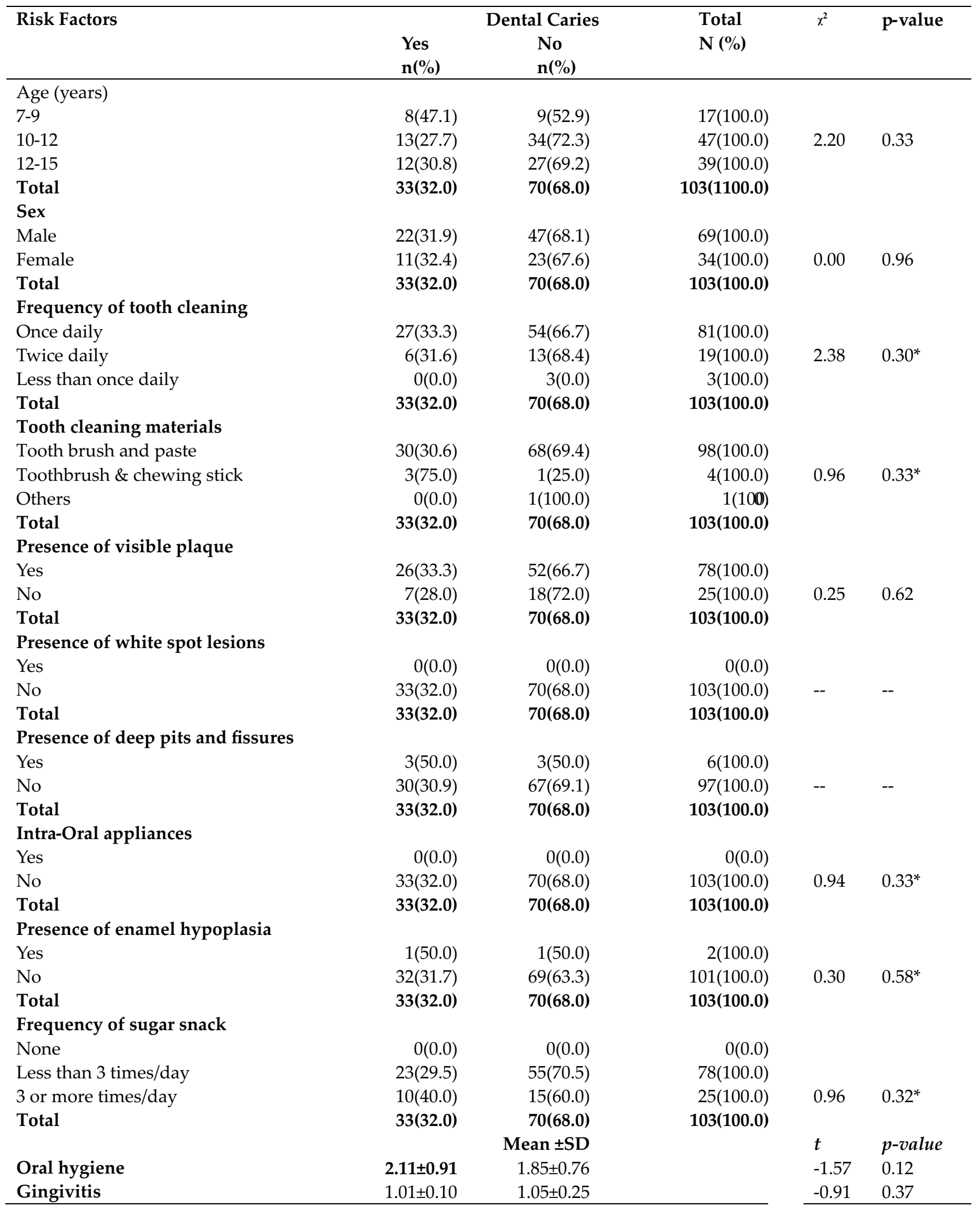

\footnotetext{
${ }^{*}$ Fisher's Exact Test Values
} 
Table 5: Association between the predictors of dental trauma and prevalence among the children

\begin{tabular}{|c|c|c|c|c|c|}
\hline \multirow{3}{*}{ Risk Fa ctors } & \multicolumn{3}{|c|}{ Dental trauma } & \multirow[t]{3}{*}{$x^{2}$} & \multirow[t]{3}{*}{ p-value } \\
\hline & Yes & No & Total & & \\
\hline & $\mathbf{N}(\%)$ & N (\%) & $\mathrm{N}(\%)$ & & \\
\hline \multicolumn{6}{|l|}{ Age } \\
\hline $7-9$ & $2(9.5)$ & 19(90.5) & $21(100.0)$ & \multirow{4}{*}{$0.16^{*}$} & \multirow{4}{*}{$3.61^{*}$} \\
\hline $10-12$ & $10(15.6)$ & $54(84.4)$ & $64(100.0)$ & & \\
\hline $13-15$ & $14(26.4)$ & $39(73.6)$ & $53(100.0)$ & & \\
\hline Total & $26(18.8)$ & $112(81.2)$ & $138(100.0)$ & & \\
\hline \multicolumn{6}{|l|}{ Sex } \\
\hline Male & $21(23.1)$ & $70(76.9)$ & $91(100.0)$ & \multirow{3}{*}{0.08} & \multirow{3}{*}{3.14} \\
\hline Female & $5(10.6)$ & $42(89.4)$ & $47(100.0)$ & & \\
\hline Total & $26(18.8)$ & $112(81.2)$ & $138(100.0)$ & & \\
\hline \multicolumn{6}{|l|}{ Lip competence } \\
\hline Competent & $15(15.0)$ & $85(85.0)$ & $100(100.0)$ & \multirow{4}{*}{0.10} & \multirow{4}{*}{4.71} \\
\hline Potentially competent & $10(32.3)$ & $21(67.7)$ & 31(100.0) & & \\
\hline Incompetent & $1(14.3)$ & $6(85.7)$ & $7(100.0)$ & & \\
\hline Total & $26(18.8)$ & $112(81.2)$ & $138(100.0)$ & & \\
\hline \multicolumn{6}{|l|}{ Anterior open bite } \\
\hline Present & $2(25.0)$ & $6(75.0)$ & $8(100.0)$ & \multirow{3}{*}{$0.65^{*}$} & \multirow{3}{*}{$0.21^{*}$} \\
\hline Absent & $24(18.5)$ & $106(81.5)$ & $130(100.0)$ & & \\
\hline Total & $26(18.8)$ & $112(81.2)$ & $138(100.0)$ & & \\
\hline \multicolumn{6}{|c|}{ Angles class of occlusion } \\
\hline Class I & $26(19.4)$ & 108(80.6) & $134(100.0)$ & \multirow{3}{*}{$1.00^{*}$} & \multirow{3}{*}{$0.96^{*}$} \\
\hline Class II (Division 1) & $0(0.0)$ & $4(100.0)$ & $4(100.0)$ & & \\
\hline Total & $26(18.8)$ & $112(81.2)$ & $138(100.0)$ & & \\
\hline \multicolumn{6}{|l|}{ Over-jet Measurement } \\
\hline $0-4 \mathrm{~mm}$ & $26(19.3)$ & 109(80.7) & 135(100.0) & \multirow{3}{*}{$1.00^{*}$} & \multirow{3}{*}{$0.71^{*}$} \\
\hline$>4 \mathrm{~mm}$ & $0(0.0)$ & $3(100.0)$ & $3(100.0)$ & & \\
\hline Total & $26(18.8)$ & $112(81.2)$ & $138(100.0)$ & & \\
\hline \multicolumn{6}{|l|}{ Substance use } \\
\hline Yes & $20(16.9)$ & $98(83.1)$ & $118(100.0)$ & \multirow{3}{*}{0.17} & \multirow{3}{*}{1.91} \\
\hline No & $6(30.0)$ & $14(70.0)$ & $20(100.0)$ & & \\
\hline Total & $26(18.8)$ & $112(81.2)$ & $138(100.0)$ & & \\
\hline
\end{tabular}

*Fisher's Exact Test values 
Table 6: Association between presenc e of predictors of dental trauma and prevalence among institutionalized street children

\begin{tabular}{|c|c|c|c|c|c|}
\hline \multirow[t]{4}{*}{ Risk Factors } & \multicolumn{3}{|c|}{ Dental trauma } & \multirow[t]{4}{*}{$x^{2}$} & \multirow[t]{4}{*}{$p$-value } \\
\hline & Yes & No & Total & & \\
\hline & N (\%) & N (\%) & N (\%) & & \\
\hline & $9(100.0)$ & $26(100.0)$ & $35(100.0)$ & & \\
\hline \multicolumn{6}{|l|}{ Age } \\
\hline $7-9$ & $1(25.0)$ & $3(75.0)$ & $4(100.0)$ & \multirow{4}{*}{1.77} & \multirow{4}{*}{$0.41^{*}$} \\
\hline $10-12$ & $6(35.3)$ & $11(64.7)$ & $17(100.0)$ & & \\
\hline $13-15$ & $2(14.3)$ & 12(85.7) & $14(100.0)$ & & \\
\hline Total & $9(25.7$ & $26(74.3)$ & $35(100.0)$ & & \\
\hline \multicolumn{6}{|l|}{ Sex } \\
\hline Male & $6(27.3)$ & $16(72.7)$ & $22(100.0)$ & \multirow[t]{3}{*}{0.08} & \multirow[t]{3}{*}{$0.80^{*}$} \\
\hline Female & $3(23.1)$ & $10(76.9)$ & $13(100.0)$ & & \\
\hline Total & $9(25.7)$ & $2(74.3)$ & $35(100.0)$ & & \\
\hline \multicolumn{6}{|l|}{ Lip competence } \\
\hline Competent & $1(5.0)$ & 19(95.0) & $20(100.0)$ & \multirow{4}{*}{11.3} & \multirow{4}{*}{$0.04^{*}$} \\
\hline Poten tially competent & $7(58.3)$ & $5(41.7)$ & $12(100.0)$ & & \\
\hline Incompetent & 1(33.3) & $2(66.7)$ & $3(100.0)$ & & \\
\hline Total & $9(25.7)$ & $26(74.3)$ & $35(100.0)$ & & \\
\hline \multicolumn{6}{|l|}{ Anterior open bite } \\
\hline Present & 1(33.3) & $2(66.7)$ & $3(100.0)$ & \multirow{3}{*}{0.10} & \multirow{3}{*}{$0.75^{*}$} \\
\hline Absent & $8(25.0)$ & $24(75.0)$ & $32(100.0)$ & & \\
\hline Total & $9(25.7)$ & $26(74.3$ & $35(100.0)$ & & \\
\hline \multicolumn{6}{|l|}{ Angles class of occlusion } \\
\hline Class I & $9(27.3)$ & $24(72.7)$ & $33(100.0)$ & \multirow{4}{*}{0.73} & \multirow{4}{*}{$0.39^{*}$} \\
\hline Class II (Division 1) & $0(0.0)$ & $2(100.0)$ & $2(100.0)$ & & \\
\hline Class II (Division 2) & $0(0.0)$ & $0(0.0)$ & $0(0.0)$ & & \\
\hline Total & $9(25.7)$ & $26(74.3)$ & $35(100.0)$ & & \\
\hline \multicolumn{6}{|l|}{ Over -jet Measurement } \\
\hline Reversed Over -jet & $0(0.0)$ & $0(0.0)$ & $0(0.0)$ & \multirow{4}{*}{-} & \multirow{4}{*}{ - } \\
\hline $0-4 \mathrm{~mm}$ & $9(25.7)$ & $26(74.3)$ & $35(100.0)$ & & \\
\hline$>4 \mathrm{~mm}$ & $0(0.0)$ & $0(0.0)$ & $0(0.0)$ & & \\
\hline Total & $9(25.7)$ & $26(74.3)$ & $35(100)$ & & \\
\hline \multicolumn{6}{|l|}{ Substance use } \\
\hline Yes & $0(0.0)$ & $2(100.0)$ & $2(100.0)$ & \multirow{3}{*}{0.73} & \multirow{3}{*}{$0.40^{*}$} \\
\hline No & $9(27.3)$ & $24(72.7)$ & $33(100.0)$ & & \\
\hline Total & $9(25.7)$ & $26(74.3)$ & $35(100.0)$ & & \\
\hline
\end{tabular}

${ }^{*}$ Fisher's Exact Test values 
Table 7: Association between predictors of dental trauma and prevalence among non-institutionalized street children

\begin{tabular}{|c|c|c|c|c|c|}
\hline \multirow[t]{4}{*}{ Risk Factors } & \multicolumn{3}{|c|}{ Dental trauma } & \multirow[t]{4}{*}{$\chi^{2}$} & \multirow[t]{4}{*}{ p-value } \\
\hline & Yes & No & Total & & \\
\hline & $\mathbf{N}(\%)$ & $\mathbf{N}(\%)$ & $\mathbf{N}(\%)$ & & \\
\hline & $17(100.0)$ & $86(100.0)$ & $103(100.0)$ & & \\
\hline \multicolumn{6}{|l|}{ Age } \\
\hline $7-9$ & $1(5.9)$ & $16(94.1)$ & $17(100.0)$ & \multirow{4}{*}{9.33} & \multirow{4}{*}{$0.01 *$} \\
\hline $10-12$ & $4(8.5)$ & $43(91.5)$ & $47(100.0)$ & & \\
\hline $13-15$ & $12(30.8)$ & $27(69.2)$ & $39(100.0)$ & & \\
\hline Total & 17(16.5) & $86(83.5)$ & $103(100.0)$ & & \\
\hline \multicolumn{6}{|l|}{ Sex } \\
\hline Male & $15(21.7)$ & $54(78.3)$ & $69(100.0)$ & \multirow{3}{*}{4.16} & \multirow{3}{*}{$0.04 *$} \\
\hline Female & $2(5.9)$ & $32(94.1)$ & $34(100.0)$ & & \\
\hline Tot al & $17(16.5)$ & $86(83.5)$ & $103(100.0)$ & & \\
\hline \multicolumn{6}{|l|}{ Lip competence } \\
\hline Competent & $14(17.5)$ & $66(82.5)$ & $80(100.0)$ & \multirow{4}{*}{0.85} & \multirow{4}{*}{$0.65^{*}$} \\
\hline Potentially competent & $3(15.8)$ & $16(84.2)$ & $19(100.0)$ & & \\
\hline Incompetent & $0(0.0)$ & $4(100.0)$ & $4(100.0)$ & & \\
\hline Total & $17(16.5)$ & $86(83.5)$ & $103(100.0)$ & & \\
\hline \multicolumn{6}{|l|}{ Anterior open bite } \\
\hline Present & $1(20.0)$ & $4(80.0)$ & $5(100.0)$ & \multirow[t]{3}{*}{0.05} & \multirow[t]{3}{*}{0.83} \\
\hline Absent & $16(16.3)$ & $82(83.7)$ & $98(100.0)$ & & \\
\hline Total & $17(16.5)$ & $86(83.5)$ & $103(100.0)$ & & \\
\hline \multicolumn{6}{|c|}{ Angles class of occlusion } \\
\hline Class I & $17(16.8)$ & $84(83.2)$ & 101(100.0) & \multirow{4}{*}{0.40} & \multirow{4}{*}{$0.53^{*}$} \\
\hline Class II (Divis ion 1) & $0(0.0)$ & $2(100.0)$ & $2(100.0)$ & & \\
\hline Class II (Division 2) & $0(0.0)$ & $0(0.0)$ & $0(0.0)$ & & \\
\hline Total & $17(16.5)$ & $86(83.5)$ & $103(100.0)$ & & \\
\hline \multicolumn{6}{|l|}{ Over -jet Measurement } \\
\hline Reversed Over -jet & $0(0.0)$ & $0(0.0)$ & $0(0.0)$ & \multirow{4}{*}{0.61} & \multirow{3}{*}{$0.43^{*}$} \\
\hline $0-4 \mathrm{~mm}$ & $17(17.0)$ & $83(83.0)$ & $100(100.0)$ & & \\
\hline$>4 \mathrm{~mm}$ & $0(0.0)$ & $3(100.0)$ & $3(100.0)$ & & \\
\hline Total & $17(16.5)$ & $86(83.5)$ & $103(100.0)$ & & \\
\hline \multicolumn{6}{|l|}{ Substance use } \\
\hline Yes & $6(33.3)$ & $12(66.7)$ & $18(100.0)$ & \multirow[t]{3}{*}{4.48} & \multirow[t]{3}{*}{0.03} \\
\hline No & $11(12.9)$ & $74(87.1)$ & $85(100.0)$ & & \\
\hline Total & $17(16.5)$ & $86(83.5)$ & $103(100.0)$ & & \\
\hline
\end{tabular}

*Fisher's Exact Test values 
finding is similar to the report from many previous studies $^{14,54}$. Substance abuse is one common activity among homeless young people in many societies ${ }^{8}$. Individuals under the influence of some of these substances may be prone to violence and fall that can cause trauma to their teeth as well as any other parts of their body. This was in agreement with the findings of Cavalcanti et $\mathrm{al}^{55}$ who observed a positive association between facial fracture and alcohol consumption. Similarly, Filho et $\mathrm{al}^{56}$ and Paiva et $\mathrm{al}^{57}$ reported a positive association between dental trauma and illicit drug use and binge drinking respectively. The prevalence of dental trauma among the children, according this study, is highest between ages 13 and 15 years compared with those who are between $7-9$ and $10-12$. This has been suggested to be the result of previous dental trauma which might have occurred before the child attains the present age. It has also been observed that older children are most likely to be involved in contact sports and interpersonal violence compared to the younger age groups ${ }^{58}$. Also, as observed in this present study, anterior open bite, among other forms of malocclusion has been linked with increased risk of dental trauma in permanent dentition by previous studies ${ }^{59}$.

\section{CONCLUSION}

The prevalence of dental caries and trauma among these groups of children were high compared to the previous studies among of school children in this environment. Also, the prevalence of dental caries is lower compared to the previous studies among the children in other countries. Furthermore, dental caries is higher among non-institutionalized than institutionalized children. On the other hand, dental trauma among both groups of children is higher than the previous findings among school children in this environment and street children in other countries. Institutionalized street children have higher dental trauma prevalence compared to non-institutionalized children. The significant predictors of dental caries were gender, frequency of tooth cleaning, tooth hypoplasia, presence of visible plaque on the anterior teeth and gingivitis, while those of dental trauma were lip competence, substance use, age and gender. It is therefore recommended that more studies are to be carried out among these children in Nigeria. Also, school oral health programmes should be extended to institutions like juvenile correctional homes while dental treatments are given at subsidized rate to these children.

\section{REFERENCES}

1. Owoaje ET, Adebiyi AO, Asuzu MC. Sociodemographic characteristics of street children in rural communities undergoing urbanization. Ann Ibadan Postgrad Med. 2009;7:10-15.

2. United Nations Childrens Emergency Fund. UNICEF 2003 [Internet]. Carol Bellamy in Joberg Africas orphaned generation. 2003 [cited 2014 Apr 22].

A v a i 1 a b 1 e from:www.unicef.org/media/ media_16664.

3. Ebigbo P. Street children: the core of child abuse and neglect in Nigeria. Child Youth Environ. 2003;13:4557.

4. Odejide AO, Toye SA. A survey of the inmates of a remand home in Ibadan. Niger J Paediatr. 1976;3:52-56.

5. Bella T, Atilola O, Omigbodun O. Children within the juvenile justice system in Nigeria: psychopathology and psychosocial needs. Ann Ibadan Postgrad Med. 2010;8:349.

6. Cumber SN, Tsoka-gwegweni JM. The health profile of street children in Africa : a literature review. J Public Health Africa. 2015;6:8590.

7. Huang CC, Barreda P, Mendoza V, Guzman L, Gilbert P. A comparative analysis of abandoned street children and formerly abandoned street children in La Paz, Bolivia. Arch Dis Child. 2004;89:8216.

8. Chi D, Milgrom P. The oral health of homeless adolescents and young adults and determinants of oral health: preliminary findings. Spec Care Dent. 2010;28:23742.

9. Contreras-Bulnes R, Reyes-Silveyra LJ, FuentesAlvarez T, Escamilla-Rodriguez F, RodríguezVilchis LE. Dental caries and treatment needs in street children in Toluca, Mexico. Int Dent J. 2008;58:1348.

10. Chiu S, DiMarco MA, Prokop JL. Childhood Obesity and Dental Caries in Homeless Children. J Pediatr Heal Care. 2013;27:27883.

11. Srinivas $R$, Srinivas $P$, Viswanath V, Suresh S, Devaki T, Narayana V. Oral Health Status of Institutionalized Street Children Aged 5-15 Years In Guntur City , Andhra, Pradesh, India. Int J Sci Technol Res. 2012;1:1923.

12. Morosini IA, Oliveira D, Ferreira F, Fraiz F, Torres-Pereira C. Performance of distant 
diagnosis of dental caries by teledentistry in juvenile offenders. Telemed J E Heal. 2014;20:5849.

13. Van Harten MT. The Oral Health Status of Incarcerated Youth at a Toronto- area Youth Centre [Internet]. University of Toronto; 2012.

A v a i 1 a b 1 e f r o m :https://tspace.library. utoronto.ca/bitstream/180

7/33571/1/vanHarten_Maria_T_201211_MSc_th esis.pdf

14. Otuyemi O. Traumatic anterior dental injuries related to incisor overjet and lip competence in 12-year-old Nigerian children. Int J Paediatr Dent. 1994 p. 815.

15. Adekoya-Sofowora C, Bruimah R, Ogunbodede E. Traumatic Dental Injuries Experience in Suburban Nigerian Adolescents. Internet J Dent Sci [Internet]. $2004 ; 3: 7$. Available from:http://ispub.com/IJDS/3/1/5673

16. Adekoya-Sofowora C, Adesina O, Nasir W. Traumatic dental injuries in nursery school children from Ile-Ife, Nigeria. Internet J Dent Sci.2007;5:At doi: 10.5580/2094.

17. Adekoya-Sofowora C., Adesina O., Nasir W., Oginni A., Ugboko V. Prevalence and causes of fractured permanent incisors in 12-year-old suburban Nigerian schoolchildren. Dent Traumatol. 2009;25:3147.

18. Denloye OO. Fractured Anterior Teeth among Mentally Handicapped School Children in Ibadan, Nigeria. African Dent J. 1996;10:247.

19. Denloye O, Ajayi D, Lagunju I. Oral health status of children seen at a paediatric neurology clinic in a tertiary hospital in Nigeria. 2012;22.

20. Sharma S, Dua R, Sunila Sharma. Prevalence, causes, and correlates of traumatic dental injuries among seven-to-twelve-year-old school children in Dera Bassi. Contemp Clin Dent [Internet]. 2012;3:38. Availablefrom: http://www.contempclindent.org/text.asp?2012/ 3/1/38/94544

21. Reisine ST, Psoter W. Socioeconomic status and selected behavioral determinants as risk factors for dental caries. J Dent Educ [Internet]. 2001;65 : 1000916 . A v a i 1 a b 1 e f r o m : http://www.jdentaled.org/content/65/10/1009.fu 11.pdf

22. Naing L, Winn T, Rusli BN. Practical Issues in Calculating the Sample Size for Prevalence Studies. Arch Orofac Sci. 2006;1:914.
23. Black GV. A work on operative dentistry volume II: The technical procedure in filling teeth [Internet]. Volume II. Medico-Dental Publishing Company; 1908 [cited 2014 May 20]. Available from: Archive.org/details/workonoperative

24. World Health Organization. Oral Health surveys: Basic methods [Internet]. 4th ed. Geneva; 1997.93 p.Availablefrom: www.paho.org/hq/dmdocuments/2009/oh_st_e surv.pdf.

25. Hurlbutt M. CAMBR : Best Practices in Dental Caries Management [Internet]. 2011. Available from: www.ineedce.com

26. Green JC, Vermillion JR. The simplified Oral Hygiene Index. J Am Dent Assoc. 1964;68:712.

27. Clerehugh V, Kindelan S. Guidelines for periodontal screening and Management of children and adolescents under 18 Years of age [Internet]. 2012 p. 25. Available from:

http://www.bsperio.org.uk/publications/downl oads/54_090016_bsp_bspd-perio-guidelinesforthe-under-18s-2012.pdf

28. Pagadala S, Tadikonda DC. An overview of classification of dental trauma. Int Arch IntegrMed. 2015;2:15764.

29. Denloye O, Ajayi D, Bankole O. A Study of dental caries prevalence in 12-14 year old school children in Ibadan, Nigeria. Pediatr Dent J.2005;15:14751.

30. Kahabuka FK, Mbawalla HS. Oral health knowledge and practice among Dar-es-Salaam Institutionalised former street children aged 716 years. Int J dent Hyg. 2006;4:1748.

31. Ajayi M., Denloye O, Abiodun-Solanke F. The unmet treatment need of traumatized anterior teeth in selected secondary school children in Ibadan, Nigeria. Dent Traumatol. 2010;26:603.

32. Vargas-Ferreira F, Zeng J, Thomson WM, Peres MA, Demarco FF. Association between developmental defects of enamel and dental caries in schoolchildren. [Internet]. Vol. 42,Journal of dentistry. 2014. p. 5406. Available f r o m : http://www.sciencedirect.com/science/ article/pii/S0300571214000608

33. Vargas-Ferreira F, Salas MMS, Nascimento GG,Tarquinio SBC, Faggion CM, Peres $\mathrm{M}$ a, et al. Association between developmental defects of enamel and dental caries: A systematic review and meta-analysis. J Dent. 2015;43:61928.

34. Pascoe L, Seow WK. Enamel hypoplasia and 
dental caries in Australian Aboriginal children: prevalence and correlation between the two diseases. Pediatr Dent. 1994;16:1939.

35. Hong L, Levy SM, Warren JJ, Broffitt B. Association between Enamel Hypoplasia and Dental Caries in Primary Second Molar : A Cohort Study. Caries Res. 2009;43:34553.

36. Naveen Kumar PG, Bhate PM, Rai R, Mohammadi SN. Enamel hypoplasia and dental caries. Ann Trop Med Public Heal. 2016;9:901.

37. Basha S, Mohamed RN, Swamy HS. Association between enamel hypoplasia and dental caries in primary second molars and permanent first molars. Ann Trop Med Public Heal. 2016;9:411.

38. Ur-Rehman M, Mahmood N, Ur-Rehman B. The Relationship of Caries With Oral Hygiene Status and Extra Oral Risk Factors. J Ayub Med Coll Abbottabad. 2008;20:1038.

39. Wansink B, Cheney M, Chan N. Exploring comfort food preferences across age and gender. Physiol Behav. 2003;79:73947.

40. Dawani N, Nisar N, Khan N, Syed S, Tanweer N. Prevalence and factors related to dental caries among pre-school children of Saddar town, Karachi, Pakistan a cross-sectional study. BMC Oral Health. 2012;12:59.

41. Saravanan SM, Lokesh S, Polepalle T, Shewale A. Prevalence, Severity and Associated Factors of Dental Caries in 3-6 Year Old Children A Cross Sectional Study. Sci Educ Publ Sci Res to Knowledge) [Internet]. 2014;2:511. Available from:http://pubs.sciepub.com/ijdsr/2/6A/2/

42. López IY, Bustos BC, Ramos AA, Espinoza RM, Jara MN, Smith LP. Prevalence of dental caries in preschool children. Rev odon to ciênc. 2009; 24:1169.

43. Hicks J, Garcia-Godoy F, Flaitz C. Biological factors in dental caries: role of saliva and dental pla queinthedyna micprocess of demineralization and remineralization (part 1) [Internet]. Journal of Clinical Pediatric Dentistry 2 $004 \mathrm{p} .4752$. A v a i $1 \mathrm{a} \mathrm{b} 1$ e f r o m :http://pediatricdentistry.metapress.com/content /yg6m443046k50u20

44. Gupta P, Gupta N, Singh HP. Prevalence of Dental Caries in relation to Body Mass Index, Daily Sugar Intake, and Oral Hygiene Status in 12-Year-Old School Children in Mathura City: A Pilot Study. Int J Pediatr [Internet]. 2014;2014:5. A v a i l a b l e from: http://www.pubmedcentral.nih.gov/articlerend er.fcgi?artid=3945027\&tool=pmcentrez\&render type $=$ abstract

45. Moynihan P, Petersen PE. Diet, nutrition and the prevention of dental diseases. Public Health Nutr [Internet]. 2004;7:20126. Available from: http://www.journals.cambridge.org/ abstract_S1368980004000217

46. West N, Sanz M, Jepsen S, Chapple I, Tonetti M. Relationship between caries and gum disease [ I nternet]. European Federation of Periodontology. 2016 [cited 2019 Apr 25]. p. 136. Availablefrom:

https://www.efp.org/publications/projects/peri oandcaries/reports/Report.pdf

47. Batwa M, Bergström J, Batwa S. The effectiveness of chewing stick miswak on plaque removal. Saudi Dent Journal. 2006;18:12533.

48. Ezoddini-ardakani F, Shadkam MN, Fotouhi H,Kashani FB, Abbassi M, Hashemian Z, et al. Study of the effects of natural toothbrush (Salvadora persica ) in prevention of dental cariesand plaque index. Health (Irvine Calif).2012;4:6128.

49. Demirci M, Tuncer S, Yuceokur AA. Prevalence of Caries on Individual Tooth Surfaces and its Distribution by Age and Gender in University Clinic Patients. Eur J Dent. 2010;4:2709.

50. Al-Sultani HFF, Al-Azawi AM, Al-Shammari HAH. Demands and Dental Treatment Needs among Children Attending the Clinic of Pedodontics, College of dentistry. J Kufa Nurs Sci. 2013;3:9.

51. Sogi G, Bhaskar D. Dental caries and oral hygiene status of 13-14 year old school children of Davangere. J Indian Soc Pedod Prev Dent.2001;2001:1137. 52. Fonseca MS, Costa FO,Penido SRC, Cruz RA. Dental caries and gingivitis prevalence: risk factor analysis in institutionalized children. Arq bras odontol. 2010;6:108.

53. Sgan-Cohen H, Margvelashvili V, Bilder L, Kalandadze M, Gordon M, Margvelashvili M, et al. Dental caries among children in Georgia by age, gender, residence location and ethnic group. Community Dent Heal. 2014;31:1637.

54. Prabhu A, Rao P, Govindarajan M, Reddy V,Krishnakumar R, Kaliyamoorthy S. Attributes of dental trauma in a school population with active sports involvement. Asian J Sports Med 
[Internet]. 2013;4:1904. Available from: http://ovidsp.ovid.com/ovidweb.cgi?T=JS\&PA

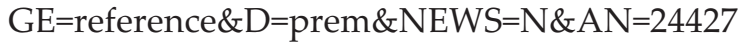
477

55. Cavalcanti AL, Bezerra KM, Oliveira DM. Maxillofacial injuries and dental trauma in patients aged 19-80 years, Recife, Brazil. Rev Española Cirugía Oral Maxilofac [Internet].2 01 0 ; $32: 116$. A v a i 1 a b 1 e f r o m : http://dx.doi.org/10.1016/S1130-0558(10)70026-5

56. Filho P, Jorge K, Paiva P, Ferreira E, Ramos-Jorge M, Zarzar P. The prevalence of dental trauma and its association with illicit drug use among adolescents. Dent Traumatol. 2014;30:1227.

57. Paiva HN, Cristina P, Paiva P, José C, Silva DP. Is There an Association between Traumatic Dental
Injury and Social Capital, Binge Drinking and $S$ o c i o e c o n o m i c I n d i c a t o r s a m o n g Schoolchildren PLoSOne. 2015;80:112.

58. Zaleckiene V, Peciuliene V, Brukiene V, Drukteinis S. Traumatic dental injuries: etiology, prevalence and possible outcomes. [Internet]. Vol. 16, Stomatologija / issued by public institution "Odontologijos studija" ... [et al.]. 2014.p.714. Availablefrom: http://www.ncbi.nlm.nih.gov/pubmed/2482405 4

59. Tümen E, Yavuz İ, Kaya S, Uysal E, Tümen D, AyY, et al. Prevalence of Traumatic Dental Injuries and Associated Factors Among 8 to 12years-old Schoolchildren in Diyarbakir, Turkey. Niger J Clin Pract. 2017;20:1259-1266. 